\title{
Nutritional value of a new type of substitute caviar
}

\author{
MONIKA MAĆKOWIAK-DRYKA, RENATA PYZ-ŁUKASIK, \\ MONIKA ZIOMEK, KRZYSZTOF SZKUCIK
}

\begin{abstract}
Department of Food Hygiene of Animal Origin, Faculty of Veterinary Medicine,
\end{abstract} University of Life Sciences in Lublin, Akademicka 12, 20-033 Lublin, Poland

\section{Maćkowiak-Dryka M., Pyz-Łukasik R., Ziomek M., Szkucik K. Nutritional value of a new type of substitute caviar}

\section{Summary}

The caviar group of products includes a subgroup of caviar substitutes. The raw material used to manufacture a substitute called white caviar are eggs of garden snails of the Cornu aspersum species. The nutritional value of every foodstuff depends on its nutrient content and caloric value. The goal of this study was to determine the nutritional value and protein quality commercially available substitute caviar manufactured from the eggs of the Cornu genus snails. The basic composition and amino acid profile were determined according to a procedure based on international standards (ISO). The carbohydrate content and caloric value were calculated according to the literature. We established that the caviar substitute had a high water content $(\mathbf{8 1 . 4 1 \% )}$ and low contents of protein $(4.23 \%)$, fat $(0.09 \%)$, carbohydrates $(6.62 \%)$, and ash $(7.65 \%)$, so that its caloric value was also low $(44.16 \mathrm{kcal} / 100 \mathrm{~g})$. The total amount of essential amino acids was 51.13 grams per 100 grams of protein, and that of non-essential amino acids was 48.37 grams per 100 grams of protein. The biological value of proteins was determined by calculating the chemical score (CS) and the essential amino acid index (EAAI). To calculate these values, we used a standard protein established by a joint FAO/WHO/UNU expert group to quantify the daily requirement for essential amino acids for an adult person. The limiting amino acid for the product in question was the sum of methionine and cysteine. CS was 130.43, and EAAI was 190.45. The chemical composition of the caviar substitute was characterized by a low content of nutrients that determine the caloric value of a product. The protein content of the product was characterized by a favourable amino acid composition and a high nutritional value measured by the CS and EAAI indicators. However, due to the low protein content and the low quantity of the product consumed, it is not a foodstuff significant to meeting the daily requirement for essential amino acids for an adult person.

Keywords: substitute caviar, snail eggs, nutritive value, chemical composition, amino acid

Known all over the world, caviar is a luxurious food with health-promoting properties $(23,29)$. The raw material for caviar production consists of egg cells (oocytes) of fish, in breeding terminology referred to as roe. Commission Regulation no. 865/2006 defines caviar as "unfertilised dead processed eggs from all Acipenseriformes species, also known as roe" (24). In light of the above, the term is restricted to salted roe of fish from species belonging to the order Acipenseriformes, commonly called black caviar or true caviar.

The growing demand for caviar and the simultaneous decrease in production of black caviar are two reasons behind the search for alternative forms of this product. Caviar products currently available on the market divide into several categories, depending on the type of the raw material. One of these consists of caviar substitutes, which can further be divided into two groups: caviar substitutes produced from eggs of fish other than those from the sturgeon family, and substitutes produced from eggs of species other than fish (4). Such substitutes are produced from eggs of over 38 fish species and 3 other animal species (4). An example of a substitute produced from eggs of a species other than fish is the so-called white caviar, produced from eggs of garden snails (Cornu aspersum) (4). In Poland, these snails are bred under farm conditions, and the main edible material obtained from them is known as snail meat (20). Substitutes produced from snail eggs differ from traditional caviar and caviar substitutes containing roe of other fish mainly in colour, grain size, and taste. The eggs of garden snails are spherical, and the diameter of a single egg is 3-6 mm; they are milky-white, frosted, and non-translucent (27). Their taste is described as earthy-nut or mushroom-oak (15). 
The goal of this study was to determine the nutritional value and protein quality of a caviar substitute produced from the eggs of garden snails from the Cornu aspersum species.

\section{Material and methods}

The study was carried out using a finished product weighing $50 \mathrm{~g}$, in glass packaging, available on the Polish market under the market name Snail Eggs. The raw material for production of this caviar substitute were eggs from both subspecies of garden snails (Cornu aspersum aspersum small common garden snail and Cornu aspersum maxima - large common garden snail). A production scheme for this foodstuff is presented in Fig. 1.
Study samples were delivered to the laboratory under cold storage conditions (temperature $0^{\circ} \mathrm{C}-+4^{\circ} \mathrm{C}$ ) within 24 hours of harvesting. The chemical composition and amino acid profile of the protein were determined in accordance with an accredited internal laboratory procedure based on international standards (ISO). The total carbohydrate content and caloric value were calculated according to the literature. The total protein content was determined by the Kjeldahl method (8), the fat content by the Soxhlet method (7), the water content by drying the sample at $103^{\circ} \mathrm{C}(9)$, and the total ash content by incineration at $550^{\circ} \mathrm{C}(10)$. The percentage of carbohydrates was calculated as follows: $\%$ of all carbohydrates $=100 \%-(\%$ water $+\%$ fat + $\%$ protein $+\%$ ash) (33). The caloric value was calculated using the Atwater system: $4 \mathrm{kcal} / \mathrm{g}$ for protein and carbohydrates, and $9 \mathrm{kcal} / \mathrm{g}$ for fat (14). The protein amino acid profile was determined by High Performance Liquid Chromatography (HPLC) $(5,6)$. The amino acid content (except for sulphur amino acids and tryptophan) was established by subjecting the sample to acid hydrolysis of protein without oxidising according to Davies and Thomas (11), whereas the content of sulphur amino acids was determined by protein hydrolysis according to Schramm et al. (25), and the content of tryptophan by base hydrolysis according to Sławiński and Tyczkowska (26). Chromatographic analysis was performed in an AAA 400 Ingos amino acid analyzer (Czech Republic). The chromatograms were analyzed using the CHROMuLAN $\mathrm{V} 0.88$ program by comparison with the standard chromatogram, taking into account the dilution and weight. All analyses were performed in duplicate.

The biological value of protein was determined by calculating the chemical score (CS) according to Block and Mitchell (3) and the integrated essential amino acid index (EAAI) according to Oser (19). The calculation of the above indexes was based on a standard protein established by a joint $\mathrm{FAO} / \mathrm{WHO} /$ UNU expert group, which determines the daily essential amino acid demand for an adult person, as presented in Tab. 1 (22).

The statistical analysis of the results was made using SAS Enterprise Guide 5.1 (SAS Institute, USA). Arithmetic means and standard deviation were calculated.

Fig. 1. Manufacturing scheme for salted snail eggs 


\section{Results and discussion}

The nutritional value of any foodstuff, including caviar substitutes, depends on its caloric value and nutrient content (28). The results of the chemical composition analysis of the Snail Eggs caviar substitute are shown in Tab. 2. The dominant component of this product was water $(81.41 \%)$. The content of other basic components, i.e. protein $(4.23 \%)$, fat $(0.09 \%)$, carbohydrates $(6.62 \%)$, and ash $(7.65 \%)$, was low, which resulted in a low caloric value of the product $(44.16 \mathrm{kcal})$. The caloric value of foodstuffs is determined largely by their water and fat contents (12). Food with a low caloric value (i.e. $30-100 \mathrm{kcal} / 100 \mathrm{~g}$ ), such as the caviar substitute in question, has a high water content and a low fat content (16). Similar protein $(4.5 \%)$ and carbohydrate levels $(6.3 \%)$ and a higher fat level $(0.3 \%)$ were found in another caviar substitute produced from the eggs of the small common garden snail (17). The results of our research are similar to those obtained in a study of the eggs of the large common garden snail (also used in this caviar substitute), which contained $84.5 \%$ of water, $6.7 \%$ of carbohydrates, $5.0 \%$ of ash, $3.7 \%$ of protein, and $0.1 \%$ of lipids (18). Górska et al. (13) found a much higher protein content (34.6-42.2\%) in the dry mass of eggs from Helix aspersa maxima (now Cornu aspersum maxima). According to the authors, it was a result of using a high-calorie, high-protein feed for the snails.
Another important factor was the month in which the eggs were harvested. Eggs from late clutches (May) had a lower protein content than those from the first clutches (March). The results of our research indicate that the subspecies of the garden snail may be a variability factor for the chemical composition of its eggs (unpublished data).

The basic composition of the Snail Eggs caviar substitute differed greatly from the basic composition of true caviars and caviar substitutes produced from the roe of fish other than the sturgeon family. According to the literature, the average content of basic components in true caviars was $57-77 \%$ water, $17-32 \%$ protein, $11-18 \%$ fat, and $1-2 \%$ ash. The content of basic components in substitutes produced from the roe of fish such as chum salmon, cod, and common perch was $50-85 \%$ water, $11.5-38 \%$ protein, $0.3-20 \%$ fat, and $0.7-2.3 \%$ ash (2). In true caviar and caviar substitutes made from fish roe, protein and fat contents were higher and water and ash levels were lower than they were in the Snail Eggs caviar substitute.

One feature that distinguished the Snail Eggs caviar substitute and other caviar substitutes produced from snail eggs was the presence of carbohydrates not found in traditional caviars produced from fish roe (16). Carbohydrate content in this type of substitutes depends on the content of polysaccharides, such as galactogen and glycogen, which are the main energetic compounds of a fertilized egg of garden snails from the Cornu genus (1). According to the data presented here, the caviar substitute produced from the eggs of garden snails had low nutritional value compared to other groups of caviar products.

The amino acid profile of the protein in the caviar substitute is shown in Tab. 3. The sum contents of essential and non-essential amino acids were, respectively, 51.13 and $48.37 \mathrm{~g} / 100 \mathrm{~g}$ protein. Among essential amino acids, the most abundant in $100 \mathrm{~g}$ of protein were aromatic amino acids (phenylalanine and tyrosine - total sum of $10.10 \mathrm{~g}$ ) followed by leucine $(8.11 \mathrm{~g})$, lysine $(6.73 \mathrm{~g})$, valine and threonine (5.66 g and $5.63 \mathrm{~g}$, respectively), tryptophan, and isoleucine $(4.87 \mathrm{~g}$ and $4.59 \mathrm{~g}$, respectively); the least abundant were sulphur

amino acids (methionine

caloric value of the Snail Eggs caviar substitute

\begin{tabular}{|l|r|}
\hline \multicolumn{1}{|c|}{ Parameter (\%) } & $\begin{array}{r}\text { Caviar substitute } \\
(\overline{\mathrm{x}} \pm \mathrm{S}) ;(\mathrm{n}=10)\end{array}$ \\
\hline Protein & $4.23 \pm 0.20$ \\
Fat & $0.09 \pm 0.07$ \\
Water & $81.41 \pm 1.06$ \\
\hline Ash & $7.65 \pm 1.51$ \\
\hline Carbohydrates & $6.62 \pm 0.52$ \\
\hline Caloric value (kcal/100g) & $44.16 \pm 2.58$ \\
\hline
\end{tabular}

\begin{tabular}{|l|r|}
\hline EAAI & \multicolumn{1}{|c|}{190.45} \\
\hline Asparaginic acid & $11.34 \pm 0.09$ \\
\hline Serine & $7.22 \pm 0.15$ \\
\hline Glutamic acid & $11.50 \pm 0.29$ \\
\hline Proline & $4.34 \pm 0.34$ \\
\hline Glycine & $3.74 \pm 0.21$ \\
\hline Alanine & $4.79 \pm 0.30$ \\
\hline Arginine & $5.44 \pm 0.23$ \\
\hline Total sum of non-essential amino acids & $48.37 \pm 0.21$ \\
\hline
\end{tabular}


and cysteine - total sum of $3.00 \mathrm{~g}$ ) and histidine $(2.45 \mathrm{~g})$. The content levels of individual amino acids determined by our study were different from the content of these amino acids in caviars and other caviar substitutes given by Rehbein (21). What is important, however, is that the content of essential amino acids in these products (with the exception of tryptophan) could meet the daily requirement for these amino acids in relation to standard protein for an adult person (22). The lack of data for tryptophan (whose content is undetermined or insignificant) makes it impossible to evaluate the nutritional value of listed products.

Among non-essential amino acids, the most abundant in the caviar substitute were glutamic and asparaginic acids (11.50 g and $11.34 \mathrm{~g}$, respectively), followed by serine (7.22 g), arginine (5.44 g), alanine and proline (4.79 $\mathrm{g}$ and $4.34 \mathrm{~g}$, respectively), and glycine (3.74 g). Compared to the caviar substitute in question, true caviars contained more glutamic acid, serine, arginine, and alanine, a comparable amount of proline, and lower levels of asparaginic acid and glycine. On the other hand, in fish-roe-based caviar substitutes the content levels of glutamic acid, alanine, and proline were higher, the level of arginine was similar, and that of asparaginic acid was lower (21).

The biological value of protein in the caviar substitute was determined in relation to a standard protein by calculating the chemical score (CS) and the integrated essential amino acid index (EAAI). The results showed that the level of all essential amino acids in protein in the caviar substitute was higher than it is in the standard protein, which indicates that $100 \mathrm{~g}$ of the protein in the caviar substitute could fully meet the daily amino acid demand for an adult person. The limiting amino acid was the sum of sulphur amino acids: methionine and cysteine. CS (130.43) and EAAI (190.45) indicated a high nutritional value of the protein in the product. Thus, the caviar substitute produced from the eggs of snails from the Cornu aspersum species had a favourable amino acid content, and its protein was of high biological value. However, due to the low protein content in the caviar substitute $(4.23 \%)$, it would take a very large quantity of "white caviar" to meet the daily essential amino acid requirement for an adult person, which rules it out as an important foodstuff in this respect.

Analysis of the impact of processing on the chemical composition of the product (Fig. 1.) showed that the production process greatly influenced the content of water, mineral compounds, and carbohydrates (unpublished data). Compared with the raw material, the final product had a lower water level and higher levels of mineral compounds and carbohydrates. Protein and fat contents in the raw material and the final product were similar.

To conclude, the present study is the first to present a complex evaluation of the basic composition and amino acid profile of the caviar substitute Snail Eggs produced from the eggs of the edible_garden snail Cornu aspersum. The nutrient content and caloric value of the product were low. The caviar substitute contained protein with a favourable amino acid content and a high nutritional value, as measured by $\mathrm{CS}$ and EAAI indexes. However, due to its low protein levels and the usually small amounts consumed at once, it is not a foodstuff of high importance in meeting the daily essential amino acid requirement for an adult person.

\section{References}

1. Bayne C. J.: A study of the desiccation of egg capsules of eight gastropod species. J. Zoology 1968, 155, 401-411.

2. Bledsoe G. E., Bledsoe C. D., Rasco B.: Caviars and fish roe products. Critical Rev. Food Sci. Nutr. 2003, 43, 317-356.

3. Block R. J., Mitchell H. H.: The correlation of amino acid composition of proteins with their nutritive value. Nutr. Abst. Rev. 1949, 16, 249.

4. Bronzi P., Rosenthal $H$.: Present and future sturgeon and caviar production and marketing: A global market overview. J. Appl. Ichthyol. 2014, 30, 1536-1546.

5. CLA/PLC/20/2011 Oznaczenie tryptofanu w produktach pochodzenia zwierzęcego metodą HPLC

6. CLA/PLC/34/2011 Oznaczenie aminokwasów ogólnych i siarkowych.

7. CLA/PSO/10/2013 Oznaczenie zawartości tłuszczu metodą wagową.

8. CLA/PSO/13/2013 Procedura uniwersalna na oznaczenie azotu i białka metodą Kjeldahla.

9. CLA/PSO/3/2013 Oznaczenie wilgotności metodą wagową.

10. CLA/PSO/5/2013 Oznaczenie popiołu.

11. Davis M. G., Thomas A. J.: An investigation of hydrolytic techniques for the amino acid analysis of foodstuffs. J. Sci. Food Agric. 1973, 24, 1525-1540.

12. Gawęcki J., Hryniewiecki L.: Żywienie człowieka. Podstawy nauki o żywieniu. PWN, Warszawa 2000.

13. Górka A., Oklejewicz B., Duda M.: Nutrient Content and Antioxidant Properties of Eggs of the Land Snail Helix aspersa maxima. J. Nutr. Food Sci. 2017, 7, 594.

14. Jabeen F., Chaudhry A. S.: Chemical compositions and fatty acid profiles of three freshwater fish species. Food Chem. 2011, 125, 991-996.

15. Kolman R., Jankowska B., Kwiatkowska A., Georgian H., Michałowski L.: Kawior nie tylko z ikry jesiotra. Kom. Ryb. 2010, 117, 31-33.

16. Maćkowiak-Dryka M.: Wartość odżywcza i jakość mikrobiologiczna jajeczek ślimaków rodzaju Cornu. Rozprawa doktorska. Uniwersytet Przyrodniczy w Lublinie 2017.

17. Massari S., Pastore S.: Heliciculture and snail caviar: new trends in the food sector. Polish Society of Commodity Science, University of Economics, Kraków 2014.

18. Nunes Almeida G.: Caviar Pérola, estudo da estabilidade físico-química e microbiológica. Universidade Técnica de Lisboa. Faculdade de Medicina Veterinária. Lizbona 2014

19. Oser B. L.: An integrated essential amino acid index for predicting biological value of proteins, [in:] Protein and Amino Acid Nutritional. Academic Press, New York 1959, 295-311.

20. Paszkiewicz W., Ziomek M., Szkucik K., Maćkowiak-Dryka M.: Pozyskiwanie i jakość zdrowotna mięsa ślimaków. Med. Weter. 2014, 70, 673-679.

21. Rehbein H.: Caviare: Proximate composition, amino acid content and identification of fish species. Z. Lebensm. Unters. Forch. 1985, 180, 457-462.

22. Report of an FAO Expert Consultation. Dietary protein quality evaluation in human nutrition. FAO Food and Nutrition Paper 2013, 92, 1-66.

23. Rogińska M., Wolosiak R.: Żywność luksusowa - co wiemy o kawiorze i truflach. Przemysł Spożywczy 2011, 65, 22-25

24. Rozporządzenie Komisji (WE) $865 / 2006$ z dnia 4 maja 2006 r. ustanawiające przepisy wykonawcze do rozporządzenia Rady (WE) nr 338/97 w sprawie ochrony gatunków dzikiej fauny i flory w drodze regulacji handlu nimi.

25. Schram E., Moore S., Bigwood E. J.: Chromatographic determination of cystine as cysteic acid. Biochem. J. 1954, 57, 33-37.

26. Stawiński P., Tyczkowska K.: Warunki hydrolizy surowców i produktów paszowych przy oznaczaniu tryptofanu. Rocz. Technol. Chemii Żywn. 1974, 24, 155-163.

27. Szkucik K., Ziomek M., Maćkowiak-Dryka M., Paszkiewicz W.: Ślimaki jadalne - użytkowość, wartość odżywcza i bezpieczeństwo dla zdrowia konsumenta. Życie Wet. 2011, 86, 631-635.

28. Ustawa z dnia 25 sierpnia 2006 r. o bezpieczeństwie żywności i żywienia. Dz. U. $2006 \mathrm{Nr} 171$ poz. 1225

29. Zdrojewicz Z., Wróblewska M., Tomaszewski Ł.: Kawior - luksus czy zdrowie? Med. Rodz. 2016, 19, 201-206.

Corresponding author: Renata Pyz-Lukasik, DVM, PhD, Department of Food Hygiene of Animal Origin, Faculty of Veterinary Medicine, University of Life Sciences in Lublin, ul. Akademicka 12, 20-033 Lublin, Poland; e-mail: renata.pyz@up.lublin.pl 